Article

\title{
Terpenoid Compositions of Resins from Callitris Species (Cupressaceae)
}

\author{
Bernd R. T. Simoneit ${ }^{1, *}$, Robert E. Cox ${ }^{2}$, Daniel R. Oros ${ }^{3, *}$ and Angelika Otto ${ }^{4}$ \\ 1 Department of Chemistry, College of Science, Oregon State University, Corvallis, OR 97331, USA \\ 2 Consultant, 24 Francis Street, Blackburn, Victoria 3130, Australia; cox.robert448@gmail.com \\ 3 Consultant, 72 Marina Lakes Drive, Richmond, CA 94804, USA \\ 4 Forschungsinstitut Senckenberg, Sektion Paläeobotanik, Senckenberganlage 25, \\ 60325 Frankfurt/Main, Germany; simonellit@yahoo.de \\ * Correspondence: simonebe@oregonstate.edu (B.R.T.S.); daniel.r.oros@gmail.com (D.R.O.); \\ Tel.: +1-541-737-2081 (B.R.T.S.)
}

Received: 24 November 2018; Accepted: 18 December 2018; Published: 19 December 2018

\begin{abstract}
The environmental fate of conifer resins and their natural product compounds as mixtures is of importance for source, alteration, and transport studies. The compound compositions of resins of the common Callitris species (Cupressaceae) based on gas chromatography-mass spectrometry have not been reported. Results show that diterpenoids were the most abundant components and callitrisic acid was present in the resin extracts of all Callitris species analyzed. Significant amounts of 4-epi-pimaric and sandaracopimaric acids, with lesser communic, ozic, and lambertianic acids, were also in the mixtures. Phenolic diterpenoids, for example, ferruginol, hinokiol, were found in trace quantities in some samples. Thus, callitrisic acid and 4-epi-pimaric acid are the characteristic diterpenoids of Callitris species that are amenable to molecular biomarker analyses in geological or environmental applications.
\end{abstract}

Keywords: Callitroideae; diterpenoids; GC-MS; standards

\section{Introduction}

Natural products from plants (e.g., terpenoids of conifer resins) are preserved directly or as derivatives (diagenetic products) in the contemporary and fossil geological environments. When extracted and characterized, they are used as molecular biomarkers in organic geochemistry, paleontology, forensics, archeology, and environmental chemistry for source identification [1-14]. The application of gas chromatography-mass spectrometry (GC-MS) in the analysis of natural product mixtures extracted from plants for compound characterization can also be of utility for rapid screening in pharmacological studies [15].

The Coniferae are known as important source plants for resins and are comprised of Araucariaceae (3 genera), Cupressaceae (27 genera), Pinaceae (11 genera), Podocarpaceae (18 genera), Taxaceae (6 genera), and Sciadopityaceae (1 genus) [16]. Here we focus on the Cupressaceae, specifically the genus Callitris with 19 species, because there is a paucity on the characterization of their natural terpenoid compositions [17].

Dehydroabietic acid (abieta-8,11,13-trien-18-oic acid) is the most commonly encountered and stable molecular biomarker from conifer resins [1]. However, its epimer, callitrisic acid (abieta-8,11,13-trien-19-oic acid), has not been reported for contemporary sedimentary environments. Nevertheless, callitrisic acid and degradation products, such as 16,17-bisnorcallitrisic acid, and 9,10-seco-callitrisic acids, are found in certain ambers or their pyrolysates $[12,18,19]$. 
Callitrisic acid was isolated from Callitris columellaris wood and its structure was determined by correlation with known compounds and synthesis [20]. Additional resin acids, including 7-oxocallitrisic acid, were also reported [21]. Callitrisic acid has a restricted distribution in the extant plant kingdom, mainly in Callitris species and isolated reports for Juniperus, Calceolaria, Rabdosia, and Illicium species, the latter three belonging to Angiosperms [15,22-24]. The only other natural products reported from Callitris species are sesquiterpenoids and lignans. The sesquiterpenoids are comprised of mainly callitrisin, columellarin, and isomers in wood of C. columellaris [25-27]. The lignans podophyllotoxin and deoxypodophyllotoxin have been detected in C. drummondii and C. columellaris, respectively [28-30]. In this study only C. preissii contains numerous known and novel lignans in the total resin extract. They are a complex mixture, including seco-lariciresinols, lariciresinols, pinoresinols, and matairesinol with many syringyl moieties, and their mass spectra as the derivatized compounds with interpretations have been published [31].

Here we report a survey by GC-MS of the dominant resin components of nine common Callitris species, and an assessment of the presence of callitrisic acid in resins of closely related and other conifers.

\section{Experimental}

\subsection{Samples}

The samples were collected as hardened, freshly bled resins from the stems of various Callitris species (Cupressaceae, subfamily Callitroideae). In the case of species with no obvious resin, a branchlet was sampled and air dried prior to extraction. The samples and their source locations are given in Table 1 . The resins of other conifers were sampled and analyzed in the same manner.

Table 1. Callitris species sampled.

\begin{tabular}{lcccc}
\hline Botanical Name & Common Name & $\begin{array}{c}\text { Sample } \\
\text { Type }\end{array}$ & Sample Location & $\begin{array}{c}\text { Number of } \\
\text { Analyses }\end{array}$ \\
\hline $\begin{array}{c}\text { Callitris baileyii } \\
\text { Callitris columellaris, }\end{array}$ & Bayley's cypress pine & Resin & RBG, Melbourne, AU & 3 \\
syn. C. glauca & White cypress pine & Resin & RBG, Melbourne, AU & 4 \\
Callitris intratropica & Blue cypress & Resin & RBG, Sydney, AU & 3 \\
Callitris macleayana & Stringybark cypress & Resin & RBG, Sydney, AU & 1 \\
Callitris muelleri & Illiwara/Bush cypress & Twig & RBG, Melbourne, AU & 3 \\
Callitris oblonga & Pigmy cypress pine & Twig & RBG, Melbourne, AU & 1 \\
Callitris preissii & Rottnest Island pine & Resin & RBG, Melbourne, AU & 8 \\
Callitris rhomboidea & Port Jackson/Oyster Bay pine & Resin & RBG, Melbourne, AU & 3 \\
Callitris verrucosa & Mallee pine & Resin & RBG, Melbourne, AU & 1 \\
\hline \multicolumn{5}{c}{ AU = Australia; RBG = Royal Botanical Garden. }
\end{tabular}

\subsection{Extraction and Gas Chromatography-Mass Spectrometry}

The resin samples and dried branchlets were crushed and sonicated three times with dichloromethane:methanol (DCM:MeOH, 3:1, v/v) for $15 \mathrm{~min}$. The total extracts were combined, filtered, and concentrated with a rotary evaporator and then with nitrogen blow down (to typically 1-3 mL). Aliquots $(50 \mu \mathrm{L})$ of the total extracts were converted to trimethylsilyl (TMS) derivatives by reaction with $\mathrm{N}, \mathrm{O}-$ bis(trimethylsilyl)trifluoroactamide (BSTFA) and pyridine for $3 \mathrm{~h}$ at $70{ }^{\circ} \mathrm{C}$. Prior to GC-MS analysis, the excess silylating reagent was evaporated under a dry nitrogen stream and the sample mixture was dissolved in an equivalent volume of $n$-hexane. Other aliquots $(50 \mu \mathrm{L}$ in DCM:MeOH, 1:1 v/v) were treated with trimethylsilyldiazomethane $(20 \mu \mathrm{L}, 2 \mathrm{M}$ in $n$-hexane, Sigma-Aldrich, St. Louis, MO, USA) to methylate carboxylic acids prior to analysis. This reaction proceeded at room temperature within $30 \mathrm{~min}$, after which the excess reagent was removed with acetic acid (glacial grade), followed by blow down with nitrogen and dissolution in $n$-hexane.

GC-MS analyses of the underivatized and derivatized extracts were carried out using an Agilent model 6890 GC coupled to an Agilent model 5973 quadrupole MSD. GC-MS data were acquired with 
the associated Chemstation software. Identifications of compounds were based on comparisons with standards, literature mass spectra, Wiley 275 library data, and interpretation of mass spectrometric fragmentation patterns for unknown compounds. The mass spectra of novel compounds and their derivatives (methyl esters or TMS esters/ethers), with the basic fragmentation patterns, are also presented. The relative abundance of each significant compound was calculated using its peak area in the respective total ion current (TIC) trace and assuming the same response factor.

\section{Results and Discussion}

The sesqui- and diterpenoids identified in the resins of Callitris sp. and their relative abundances are listed in Table 2. The Kovats GC retention indices of the natural products or their derivatives relative to $n$-alkanes are given on the respective mass spectra [32].

\subsection{Resin Compositions}

The diterpenoid compositions of the samples are quite diverse, especially with regards to callitrisic acid ( $X$, the chemical structures are given in Appendix A and follow the sequence in Table 2). Some examples of total resin compositions are shown in Figure 1. Callitrisic acid $(X)$ is the dominant compound in resins from C. intratropica, C. macleayana, C. rhomboides, and C. verrucosa, a trace component in resin of C. oblonga, and minor in the other samples. Dehydroabietic acid (XI) is a trace component only in resin of C. muelleri and 16,17-bisnorcallitrisic acid is not detectable. Sandaracopimaric acid (XVI), 4-epi-pimaric acid (XII), communic acids (XIII-XV), and 12E-ozic acid (XVII) are the secondary major components (Table 2). Various hydroxycallitrisic acids (XXIII-XXVI), lambertianic acid (XXII), and 7-oxocallitrisic acid (XXI) are also significant in some of the resins. Callitrisol (V), ferruginol (VI), and sandaracopimara-8(14),15-dien-3 $\beta$-ol (VII) are minor hydroxylated components in some samples. In addition, C. preissii resin contains dominant lignans, as already reported [31]. Three sesquiterpenoids, i.e., callitrisin (I), columellarin (II), and dihydrocolumellarin (III), are present here only in resin of $C$. preissii (Figure 1c). These were reported before in heartwood of C. columellaris $[25,26]$, but not detected in our resin sample.
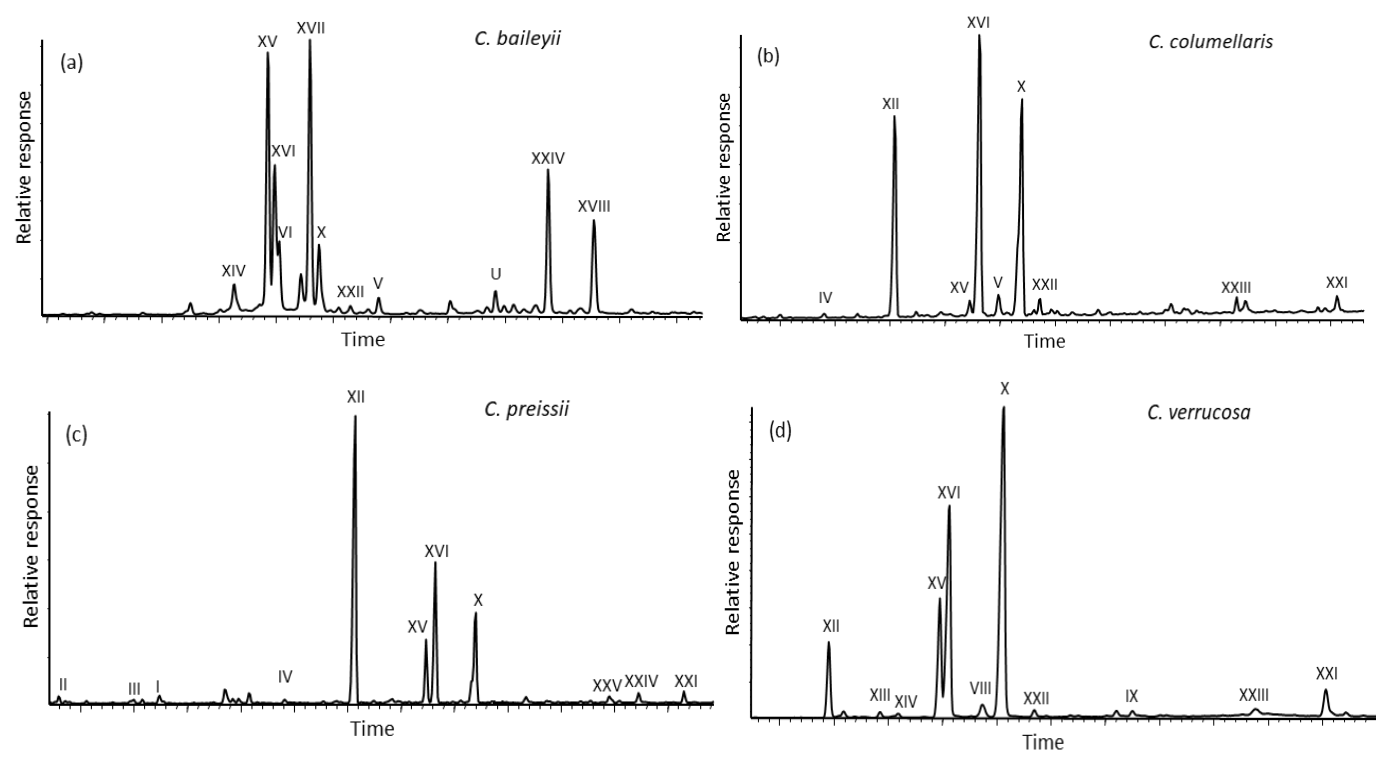

Figure 1. Examples of total ion current (TIC) traces for total extracts of Callitris species resins: (a) C. baileyii analyzed as the methylated and silylated extract, (b) C. columellaris analyzed as the methylated extract, (c) C. preissii analyzed as the methylated extract (the major lignans are not shown), and (d) C. verrucosa analyzed as the methylated extract. Roman numerals refer to the compounds in Table 2. $\mathrm{U}=$ unknown. 
Table 2. Relative concentrations of the major terpenoids in the Callitris species resins.

\begin{tabular}{|c|c|c|c|c|c|c|c|c|c|c|c|c|c|c|}
\hline Number & Compound & Composition & MW & $\begin{array}{l}\text { Kovats } \\
\text { Index }^{\text {a }}\end{array}$ & $\mathrm{ID}^{\mathrm{b}}$ & C. Bail. & C. Colum. & C. Intratr. & C. Maclea. & C. Muell. & C. Oblonga & C. Preissii & C. Rhomb. & C. Verruc. \\
\hline I & Callitrisin & $\mathrm{C}_{15} \mathrm{H}_{20} \mathrm{O}_{2}$ & 232 & 1916 & $\mathrm{~L}$ & & & & & & & 10 & & \\
\hline II & Columellarin & $\mathrm{C}_{15} \mathrm{H}_{20} \mathrm{O}_{2}$ & 232 & 1925 & $\mathrm{~L}$ & & & & & & & 24 & & \\
\hline III & Dihydrocolumellarin & $\mathrm{C}_{15} \mathrm{H}_{22} \mathrm{O}_{2}$ & 234 & 1875 & $\mathrm{~L}$ & & & & & & & 6 & & \\
\hline IV & Dehydroabietane & $\mathrm{C}_{20} \mathrm{H}_{30}$ & 270 & 2084 & $\mathrm{~s}$ & & 1 & & & & & & 0.5 & \\
\hline $\mathrm{V}$ & Callitrisol & $\mathrm{C}_{20} \mathrm{H}_{30} \mathrm{O}$ & 286 & 2152 & I & 5 & 2 & 4 & & & & 8 & & \\
\hline VI & Ferruginol & $\mathrm{C}_{20} \mathrm{H}_{30} \mathrm{O}$ & 286 & 2289 & $\mathrm{~s}$ & 20 & 0.3 & 0.2 & 0.6 & 19 & & 1.3 & & \\
\hline VII & Sandaracopimaradien- $3 \beta-\mathrm{ol}$ & $\mathrm{C}_{20} \mathrm{H}_{32} \mathrm{O}$ & 288 & 2110 & $\mathrm{~L}$ & & 7 & & & 90 & & & & \\
\hline VIII & $\Delta^{6}$-Callitrisic acid & $\mathrm{C}_{20} \mathrm{H}_{26} \mathrm{O}_{2}$ & 298 & 2318 & I & & & 8 & & & & & 8 & 4 \\
\hline IX & $\Delta^{15}$-Callitrisic acid & $\mathrm{C}_{20} \mathrm{H}_{26} \mathrm{O}_{2}$ & 298 & 2436 & I & & & & & & & & 2 & 2 \\
\hline$x$ & Callitrisic acid & $\mathrm{C}_{20} \mathrm{H}_{28} \mathrm{O}_{2}$ & 300 & 2325 & $\mathrm{~s}$ & 24 & 75 & 94 & 100 & 16 & 2.8 & 31 & 100 & 100 \\
\hline $\mathrm{XI}$ & Dehydroabietic acid & $\mathrm{C}_{20} \mathrm{H}_{28} \mathrm{O}_{2}$ & 300 & 2358 & $\mathrm{~s}$ & & & & 2 & 1.5 & 1.2 & & & \\
\hline XII & 4-epi-Pimaric acid & $\mathrm{C}_{20} \mathrm{H}_{30} \mathrm{O}_{2}$ & 302 & 2166 & I & & 69 & 26 & & & 60 & 100 & 20 & 23 \\
\hline XIII & iso-Communic acid & $\mathrm{C}_{20} \mathrm{H}_{30} \mathrm{O}_{2}$ & 302 & 2225 & $\mathrm{~L}$ & & 1 & & 11 & & & & 3 & 2 \\
\hline XIV & 12Z-Communic acid & $\mathrm{C}_{20} \mathrm{H}_{30} \mathrm{O}_{2}$ & 302 & 2263 & $\mathrm{~L}$ & 6 & & 9 & 15 & & & 1 & 2 & 1 \\
\hline $\mathrm{XV}$ & 12E-Communic acid & $\mathrm{C}_{20} \mathrm{H}_{30} \mathrm{O}_{2}$ & 302 & 2268 & $\mathrm{~L}$ & 90 & 5 & 40 & 54 & & 100 & 21 & 38 & 38 \\
\hline XVI & Sandaracopimaric acid & $\mathrm{C}_{20} \mathrm{H}_{30} \mathrm{O}_{2}$ & 302 & 2275 & $\mathrm{~s}$ & 34 & 100 & 100 & 29 & 95 & & 48 & 15 & 69 \\
\hline XVII & Ozic acid (4-epi-communic acid) & $\mathrm{C}_{20} \mathrm{H}_{30} \mathrm{O}_{2}$ & 302 & 2317 & $\mathrm{~L}$ & 100 & & & & 100 & & & & \\
\hline XVIII & 19-Hydroxyferruginol & $\mathrm{C}_{20} \mathrm{H}_{30} \mathrm{O}_{2}$ & 302 & 2517 * & $\mathrm{s}$ & 34 & & & & & & & & \\
\hline XIX & Hinokiol & $\mathrm{C}_{20} \mathrm{H}_{30} \mathrm{O}_{2}$ & 302 & 2537 * & $\mathrm{L}$ & & & & & 49 & & & & \\
\hline$x x$ & $3 \beta, 18$-Dihydroxypimara-8(14),15-diene & $\mathrm{C}_{20} \mathrm{H}_{32} \mathrm{O}_{2}$ & 304 & 2457 * & $\mathrm{L}$ & & & & & 90 & & & & \\
\hline XXI & 7-Oxocallitrisic acid & $\mathrm{C}_{20} \mathrm{H}_{26} \mathrm{O}_{3}$ & 314 & 2531 & I & & 5 & 5 & 9 & & & 5 & 16 & 12 \\
\hline XXII & Lambertianic acid & $\mathrm{C}_{20} \mathrm{H}_{28} \mathrm{O}_{3}$ & 316 & 2355 & $\mathrm{~L}$ & 3 & 5 & 3 & 4 & 12 & 4 & & 2 & 3 \\
\hline XXIII & $2 \alpha$-Hydroxycallitrisic acid & $\mathrm{C}_{20} \mathrm{H}_{28} \mathrm{O}_{3}$ & 316 & 2386 * & I & & 6 & & 4 & & & & 8 & 2 \\
\hline XXIV & 12-Hydroxycallitrisic acid & $\mathrm{C}_{20} \mathrm{H}_{28} \mathrm{O}_{3}$ & 316 & $2526 *$ & I & 52 & & & & & & & & \\
\hline $\mathrm{XXV}$ & $7 \beta$-Hydroxycallitrisic acid & $\mathrm{C}_{20} \mathrm{H}_{28} \mathrm{O}_{3}$ & 316 & 2407 * & I & & & & & & & & 8 & \\
\hline XXVI & $7 \alpha$-Hydroxycallitrisic acid & $\mathrm{C}_{20} \mathrm{H}_{28} \mathrm{O}_{3}$ & 316 & 2390 * & I & & & & & & & & 10 & \\
\hline
\end{tabular}

${ }^{\mathrm{a}}$ As free compounds or methyl esters, ${ }^{*}=\mathrm{TMS}$ derivative; ${ }^{\mathrm{b}} \mathrm{S}=$ standard, $\mathrm{L}=$ literature citation, $\mathrm{I}=$ interpretation of MS fragmentation pattern. 


\subsection{Mass Spectrometry}

The mass spectra of the compounds in Table 2, analyzed as the free and derivatized products, are shown in Figure 2. Additional mass spectra of related and derivatized natural products are collected and discussed in the Supplemental Materials.
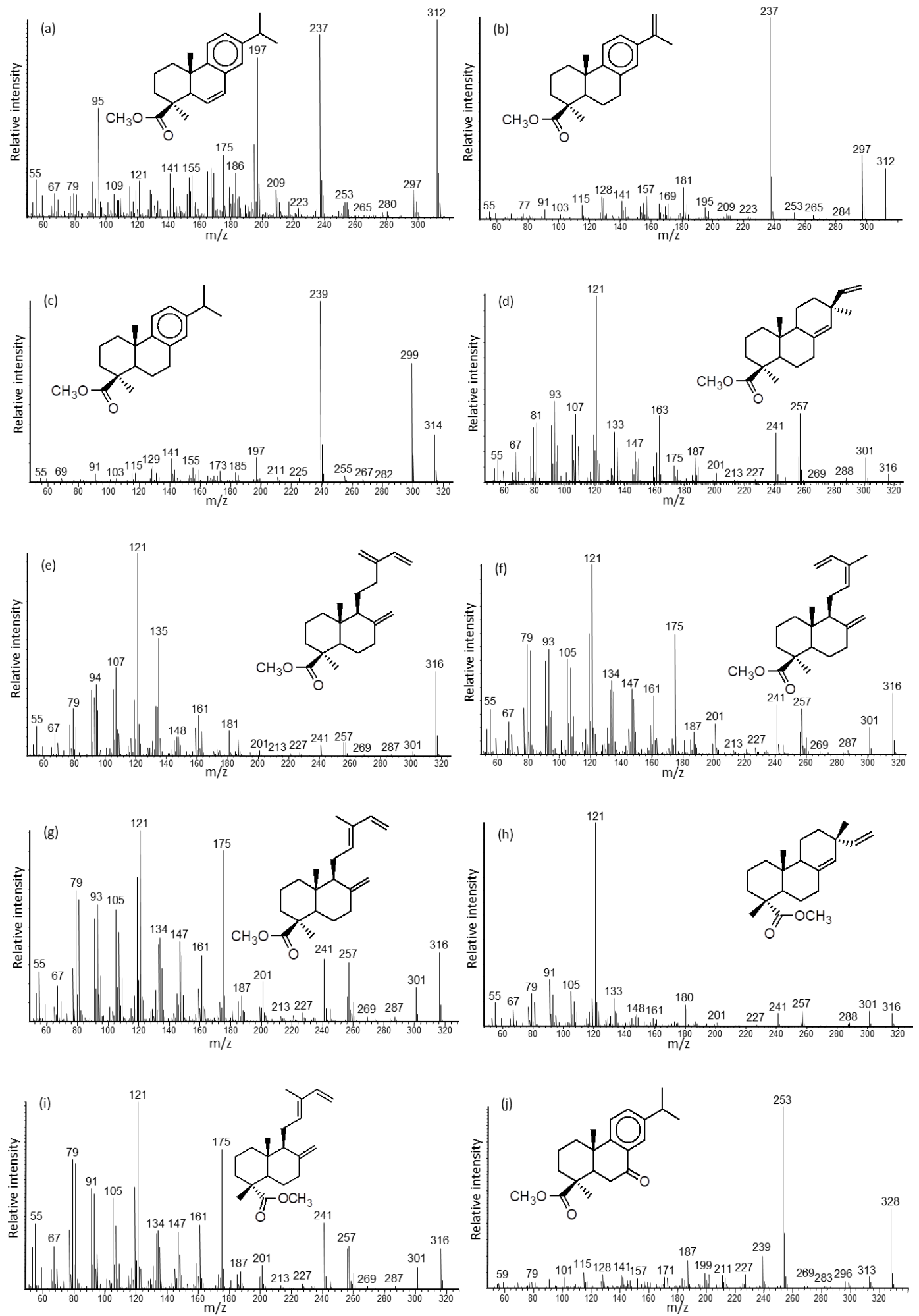

Figure 2. Cont. 

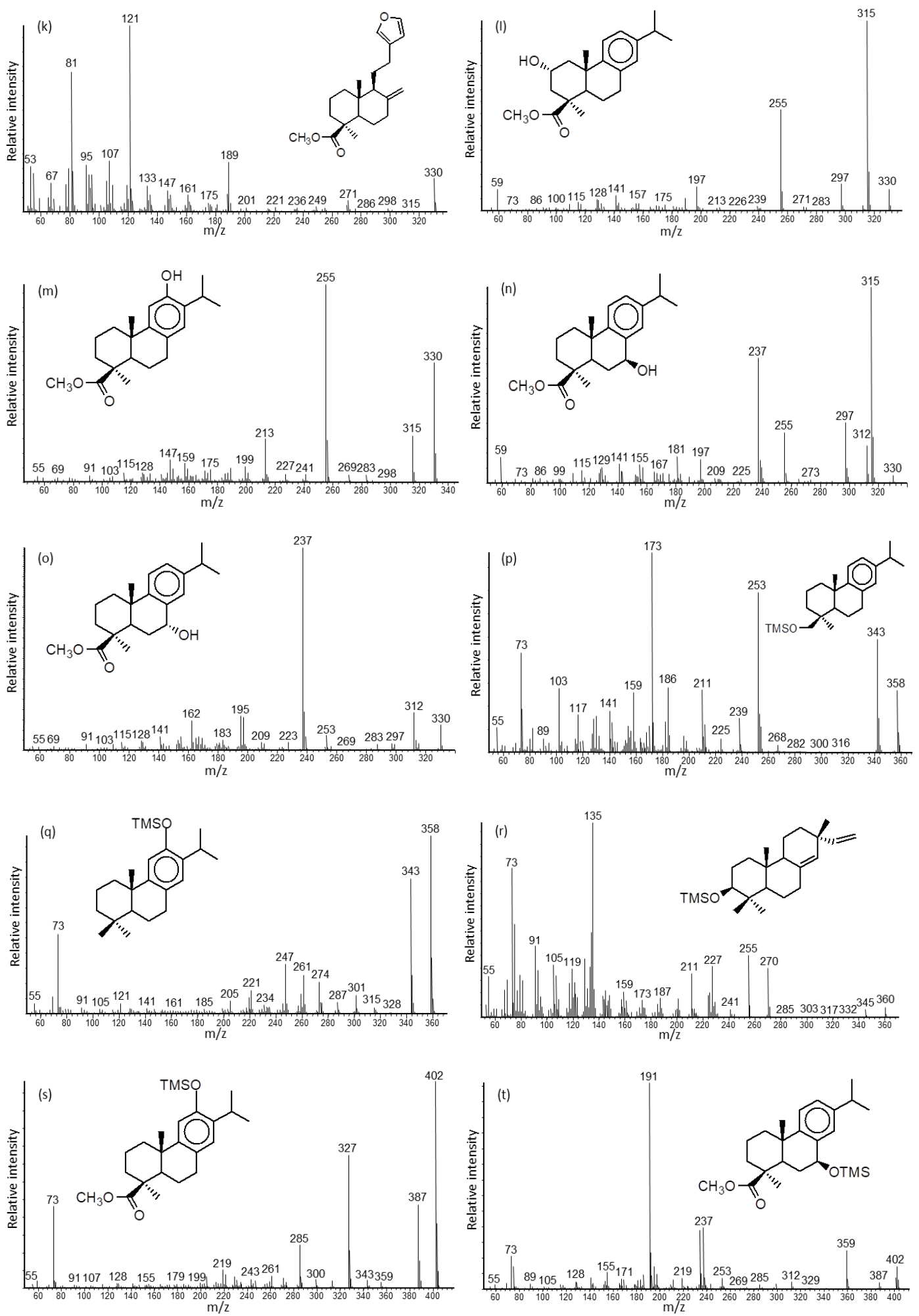

Figure 2. Cont. 

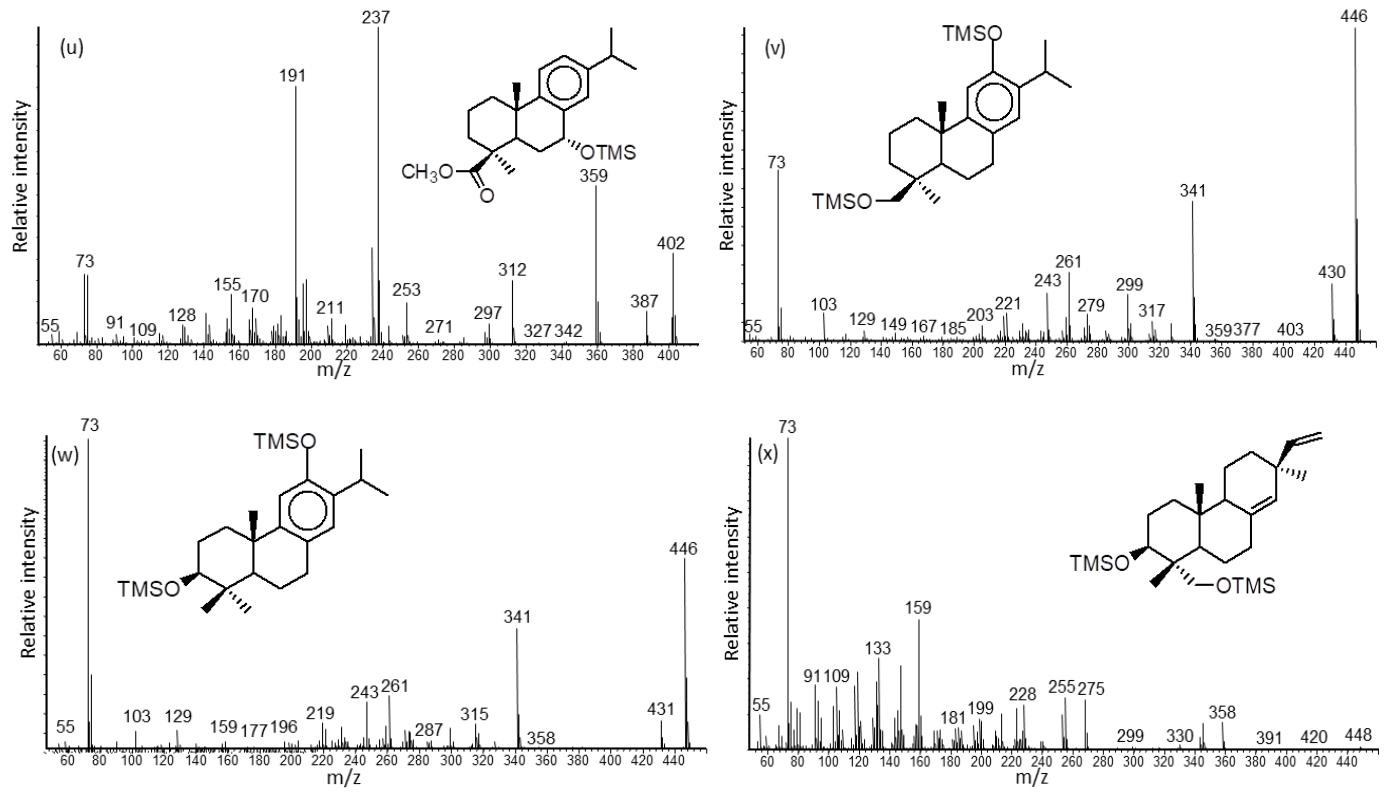

Figure 2. Mass spectra of the terpenoids listed in Table 2, analyzed as the natural products, methylated and/or silylated derivatives: (a) methyl abieta-6,8,11,13-tetraene-19-oate (VIII), (b) methyl abieta-8,11,13,15-tetraen-19-oate (IX, [33]), (c) methyl callitrisate (methyl abieta-8,11,13-trien-19-oate, X), (d) methyl 4-epi-pimarate (XII, [34]), (e) methyl iso-communate (XIII), (f) methyl 12Z-communate (XIV), (g) methyl 12E-communate (XV), (h) methyl sandaracopimarate (XVI), (i) methyl 12E-ozate (XVII), (j) methyl 7-oxocallitrisate (XXI, [21]), (k) methyl lambertianate (XXII), (l) methyl 2 $\alpha$-hydroxycallitrisate (XXIII), (m) methyl 12-hydroxycallitrisate (XXIV, [35]), (n) methyl 7 $\beta$-hydroxycallitrisate $(X X V),(\mathbf{o})$ methyl $7 \alpha$-hydroxycallitrisate (XXVI, [23]), (p) callitrisol-TMS (V), (q) ferruginol-TMS (VI), (r) sandaracopimaradien-3 $\beta$-ol (VII), (s) methyl 12-hydroxycallitrisate-TMS (XXIV), (t) methyl 7 $\beta$-hydroxycallitrisate-TMS (XXV), (u) methyl $7 \alpha$-hydroxycallitrisate-TMS (XXVI), (v) 12-hydroxycallitrisol-diTMS (XVIII), (w) hinokiol-diTMS (XIX), and (x) 3ß,18-dihydroxypimaradiene-diTMS (XX).

Callitrisic acid $(X)$ was easily distinguished from its isomers, i.e., dehydroabietic $(X I), 5 \beta$-callitrisic, $5 \beta$-dehydroabietic, and veadeiroic (cleistantha-8,11,13-trien-19-oic, [36]) acids, based on the GC retention index and mass spectrum (Figure 2c versus Figure S1r-u, Supplemental Material). The methyl esters had the best resolution and stability for analysis by GC-MS, versus their trimethylsilyl esters (Figure S1aa-cc). The key ion was $m / z 239$ with intense molecular $\left(\mathrm{M}^{+}\right)$ion at $m / z 314$ (30) and $\mathrm{M}-\mathrm{CH}_{3}$ ion at $m / z 299$ (65), compared to methyl dehydroabietate with $\mathrm{M}^{+}$at $m / z 314$ (10) and $\mathrm{M}-\mathrm{CH}_{3}$ at $m / z 299$ (11). Traceamounts of $\Delta^{6}$ - and $\Delta^{15}$-callitrisic acids (VIII, XI, respectively) were also found (Figure $2 a, b)$, and were identified by correlation with the standard isomers of methyl $\Delta^{6}$ - and $\Delta^{15}$-dehydroabietates and veadeiroates (Figure $\mathrm{S} 1 \mathrm{n}-\mathrm{q}$ ).

The presence of 4-epi-pimaric acid (XII) is of interest. The identification was based on its early GC elution and the same mass spectrum as that of pimaric acid standard (Figures $2 \mathrm{~d}$ and S1dd), coupled with a literature report [34]. The mass spectra of the communic acids (XIII-XV) and sandaracopimaric acid (XVI) match those of the respective standards (Figures 2e-h and S1ee-hh). The communic acids have been characterized for resin from C. columellaris [21]. Ozic acid (XVII, 4-epi-communic acid, assumed 12E-isomer) was a dominant component in two samples, and its mass spectra (Figures $2 \mathrm{i}$ and S1ii) were interpreted by comparison with literature data $[37,38]$ and the GC retention indices versus those of the communic acids. Lambertianic acid (XXII) is a major component in most samples and its mass spectra (Figures $2 \mathrm{k}$ and S1nn) were interpreted by comparison with a surrogate standard from resin of Pinus lambertiana [39]. 7-Oxocallitrisic acid (XXI) is a significant oxidation product in many samples and its mass spectra (Figures $2 \mathrm{j}$ and $\mathrm{S} 1 \mathrm{~mm}$ ) were interpreted by comparison with standard 7-oxodehydroabietic acid and GC retention index. 
The mass spectra of the sesquiterpenoids callitrisin (I), columellarin (II) and dihydrocolumellarin (III) were inferred from previous listings [25,26] (Figure S1a-c). The mass spectrum of dehydroabietane (IV) has been presented before [40] (Figure S1d), ferruginol (VI) matches with the standard (Figures 2q and S1f), sandaracopimaradien-3 $\beta$-ol (VII) correlates with literature data (Figures $2 \mathrm{r}$ and S1g), and hinokiol (XIX) correlates with the surrogate standard from resin of Chamaecyparis obtusa (Figures 2w and S11).

\subsection{Environmental and Geological Implications}

The environmental fate of conifer resins and their natural product compounds as mixtures is of importance for source, alteration and transport studies [10,41-43]. The precursor-product relationship for diterpenoids based on the abietane and pimarane skeletons has been presented by numerous authors $[1,42,44,45]$. Thus, callitrisic acid, 4-epi-pimaric acid, ferruginol and lambertianic acid of the Callitris resins were proposed as the main environmental tracers. Over geological timespans, the fate of the communic and ozic acids is oxidation and incorporation into macromolecular polymers. The diagenetic fate of callitrisic acid is decarboxylation with subsequent aromatization, analogous as dehydroabietic acid, to the same hydrocarbons, i.e., dehydroabietin (18- or 19-norabieta-8,11,13-triene) and retene (Figure 3). Also, 4-epi-pimaric acid may aromatize to 15,16-bisnorcallitrisic acid by loss of $\mathrm{C}_{2} \mathrm{H}_{6}$, or become incorporated into polymeric matter across the C-15 to C-16 double bond with subsequent release as the same diagenetic product (Figure 3). Bisnordehydroabietic acid may be derived by the same route from sandaracopimaric acid (Figure 3). These products are readily observed in pyrolysates of some ambers [18].
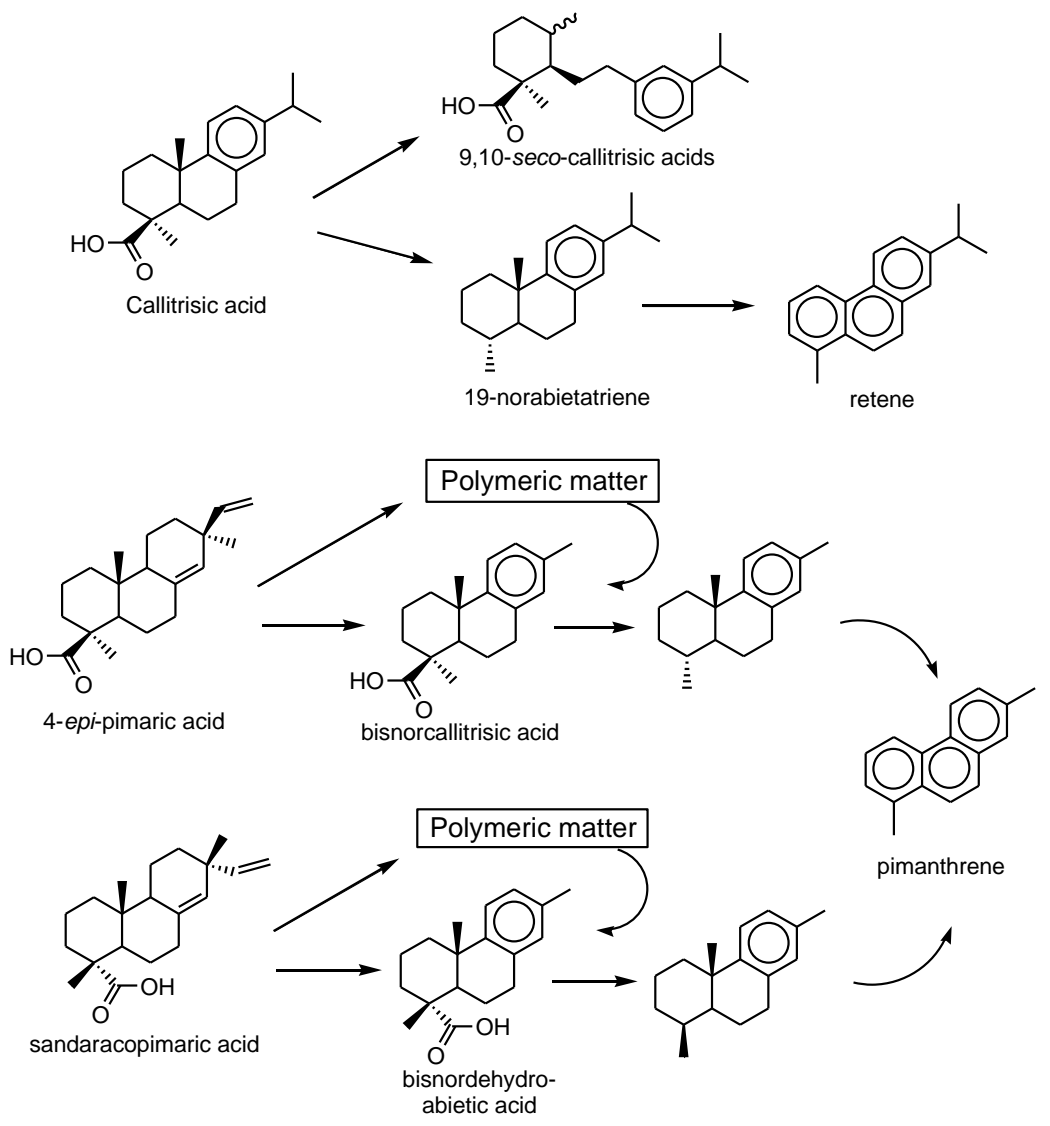

Figure 3. Diagenetic products from callitrisic, 4-epi-pimaric and sandaracopimaric acids. 
The unknown factor is whether callitrisic acid can also isomerize to dehydroabietic acid in fossil resins. Dehydroabietic acid is generally the dominant compound in total extracts of certain ambers and fossil resins, with minor or trace amounts of callitrisic acid [12,18,19,46]. We also found the seco-derivatives of both callitrisic and dehydroabietic acids in some amber extracts and commonly in aged pine resins (see the mass spectra in the Supplemental Materials). The pine resins contained dehydroabietic acid, $10 \alpha(\mathrm{H})$ - and $10 \beta(\mathrm{H})-9,10$-seco-dehydroabietic acids, and 4,5,9,10-bis-seco-dehydroabietic acid [2,6-dimethyl-9-(3'-(2-methylethyl)phenyl)non-2-enoic acid]; whereas the ambers contained both sets of seco-derivatives, but the bis-seco-compound was not found. We propose that the $10 \alpha(\mathrm{H})$ - and $10 \beta(\mathrm{H})-9,10$-seco-callitrisic acids may also proceed to the 4,5,9,10-bis-seco-derivative (Figure 4). Furthermore, we speculate if these reactions are reversible in amber, then ring reclosures may lead to epimerization at C-4.

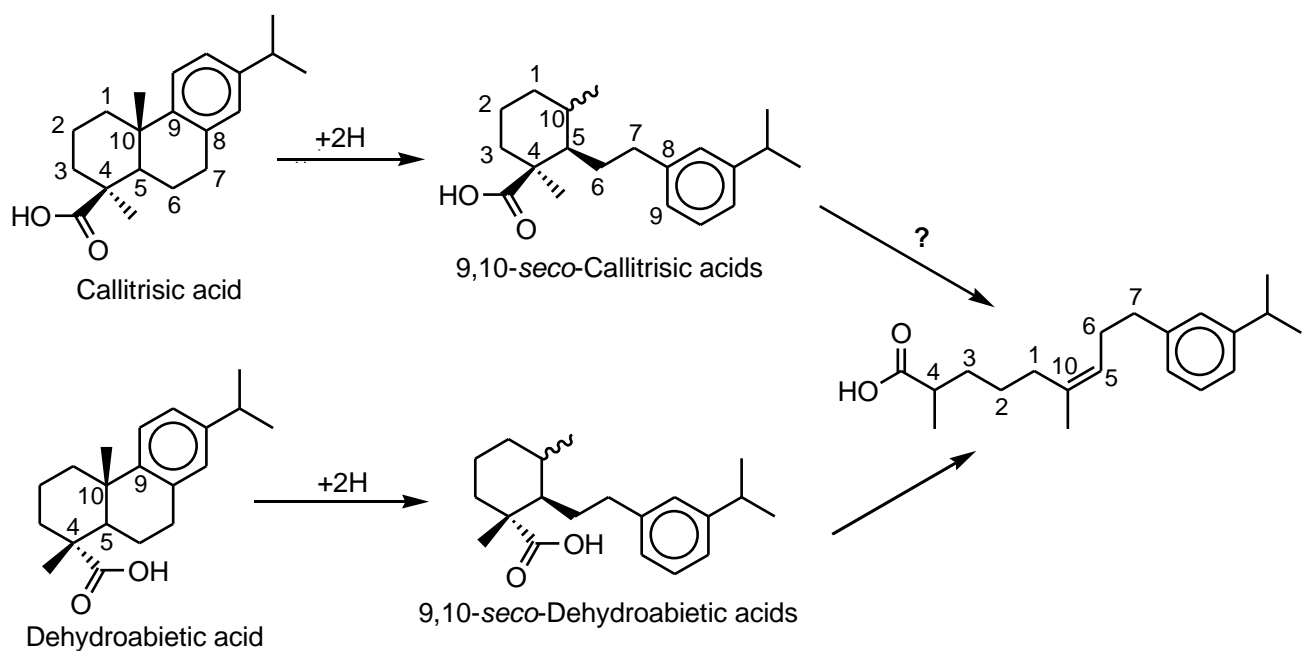

Figure 4. Ring-opening isomerization of callitrisic and dehydroabietic acids.

We found no callitrisic acid in the closely related species (e.g., Diselma archeri, Fitzroya cupressoides, Tetraclinis articulata, and Austrocedrus chilensis $[47,48])$. We were not able to detect any callitrisic acid in resins of Juniperus chinensis and J. phoenicea, as reported before $[23,49,50]$. However, we did find 4-epi-abietic and 4-epi-pimaric acids in the juniper resins we analyzed. They could dehydrogenate to the aromatic derivatives upon weathering, as for example the rapid oxidation of abietic acid to dehydroabietic acid. Macrofossils of Callitris species are rare [51], so further work on the preservation of the major resin tracer components by direct or extract analyses remains for the future.

\section{Conclusions}

Callitrisic acid was found in resin extracts of all Callitris species analyzed here. Significant amounts of 4-epi-pimaric and sandaracopimaric acids, with lesser communic, ozic, and lambertianic acids, were also in the mixtures. Phenolic diterpenoids, e.g., ferruginol, hinokiol, were found in trace amounts in some samples. Therefore, callitrisic acid and 4-epi-pimaric acid are the characteristic diterpenoids of Callitris species for molecular biomarker analyses in geological or environmental applications. Furthermore, callitrisic acid has not been found in closely related Cupressaceae species, although it is present in some Angiosperms.

Supplementary Materials: Additional mass spectra of related and derivatized natural products are collected and discussed in the Supplemental Material section available with this paper.

Author Contributions: All Authors contributed to the work; B.R.T.S. and A.O. conceived and designed the experiments; R.E.C. and B.R.T.S. obtained the resins; B.R.T.S., A.O., R.E.C., and D.R.O. performed the experiments, analyzed data, and interpreted mass spectra; B.R.T.S. wrote the original draft of the paper; A.O., R.E.C., and D.R.O. reviewed and edited the paper. 
Funding: This research received no external funding.

Acknowledgments: We thank Pinto, A.C.; Dutta, P.C.; Wenkert, E.; Cambie, R.C. and Yoshikoshi, A. for generous gifts of standard reference compounds, and the Director and Peter Syme of the Royal Botanic Gardens Melbourne, and Peter Sweedman of the Royal Botanic Gardens Sydney for permission to collect samples.

Conflicts of Interest: The authors declare no conflicts of interest.

\section{Appendix A}

Chemical structures cited.<smiles>C=C1CC=C[C@]2(C)CC3OC(=O)[C@H](C)C3CC12</smiles>

I. Callitrisin<smiles>C=C1C(=O)O[C@@H]2CC(C)=C3CC[C@H](C)C3CC12</smiles>

II. Columellarin<smiles>CC1=C2C[C@H](C)CC[C@H]2CC(=O)O[C@@H]1C</smiles>

III. Dihydrocolumellarin<smiles>CC(C)c1ccc2c(c1)CCCC2(C)C</smiles>

IV. Dehydroabietane<smiles>CC(C)c1ccc2c(c1)CCC1[C@@](C)(CO)CCC[C@@]21C</smiles>

V. Callitrisol

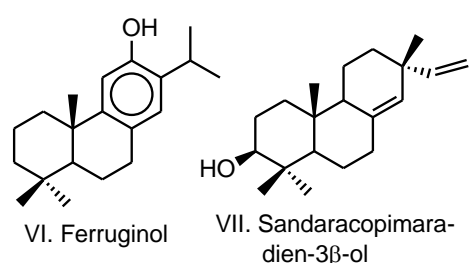<smiles>CC(C)c1ccc2c(c1)C=CCC2(C)C(=O)O</smiles>
VIII. $\Delta^{6}$-Callitrisic

$\mathrm{HO}$<smiles>C=C(C)c1ccc2c(c1)CCC1C(C)(C(=O)O)CCCC21C</smiles>
IX. $\Delta^{15}$-Callitrisic acid<smiles>CC(C)c1ccc2c(c1)CC[C@]1(C)CCCC[C@](C)(C(=O)O)[C@@]21C</smiles>

XI. Dehydroabietic acid<smiles>C=C[C@]1(C)C=C2CCC3[C@](C)(C(=O)O)CCC[C@]3(C)C2CC1</smiles>

XVI. Sandaracopimaric acid<smiles>C=C[C@]1(C)CC[C@H]2CC[C@H]3C(C)(C(=O)O)CCCC3(C)C2C1</smiles>

XII. 4-epi-Pimaric acid<smiles>C=C/C(C)=C/C[C@H]1C(=C)CCC2[C@@](C)(C(=O)O)CCC[C@@]21C</smiles>
XVII. Ozic acid<smiles>C=CC(=C)CC[C@H]1C(=C)CCC2[C@](C)(C(=O)O)CCC[C@@]21C</smiles>

XIII. Iso-communic acid<smiles>C=C/C(C)=C\C[C@H]1C(=C)CC[C@H]2C(C)(C(=O)O)CCC[C@]12C</smiles>

2Z-Communic acid<smiles>CC(C)c1cc2c(cc1O)[C@]1(C)CC[C@H](O)C(C)(C)[C@H]1CC2</smiles>

XIX. Hinokiol<smiles>[X]C(=O)[C@]1(C)CCC[C@]2(C)c3ccc(C(C)C)cc3CC[C@@H]21</smiles>

X. Callitrisic acid<smiles>C=C/C(C)=C/C[C@@H]1C(=C)CC[C@H]2C(C)(C(=O)O)CCC[C@]12C</smiles>

XV. 12E-Communic acid<smiles>C=C[C@]1(C)C=C2CCC3[C@](C)(CC[C@@H](O)[C@@]3(C)CO)[C@@H]2CC1</smiles>

XX. 3 $\beta, 18$-dihydroxypimara-8(14),15-diene

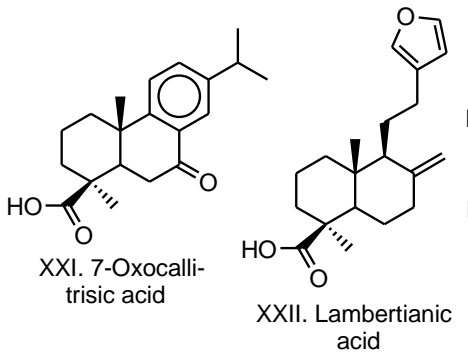

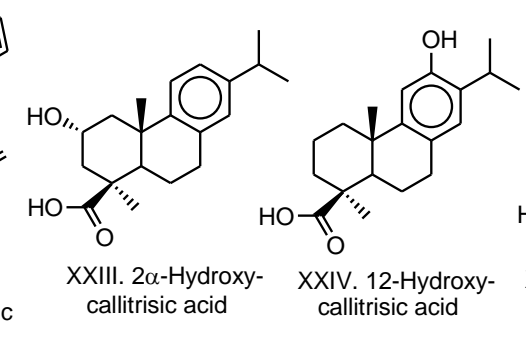

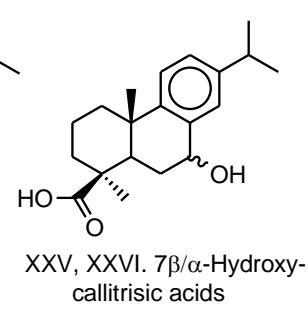

\section{References}

1. Simoneit, B.R.T. Diterpenoid compounds and other lipids in deep-sea sediments and their geochemical significance. Geochim. Cosmochim. Acta 1977, 41, 463-476. [CrossRef]

2. Simoneit, B.R.T. The organic chemistry of marine sediments. In Chemical Oceanography, 2nd ed.; Riley, J.P., Chester, R., Eds.; Academic Press: New York, NY, USA, 1978; pp. 233-311.

3. Simoneit, B.R.T. Biomarker PAHs in the environment. In the Handbook of Environmental Chemistry; Hutzinger, O., Ed.; Springer: Berlin, Germany, 1998; pp. 175-221. 
4. Simoneit, B.R.T. A review of biomarker compounds as source indicators and tracers for air pollution. Environ. Sci. Pollut. Res. Int. 1999, 6, 153-163. [CrossRef] [PubMed]

5. Simoneit, B.R.T. Biomass burning-A review of organic tracers for smoke from incomplete combustion. Appl. Geochem. 2002, 17, 129-162. [CrossRef]

6. Otto, A.; Simoneit, B.R.T. Chemosystematics and diagenesis of terpenoids in fossil conifer species and sediment from the Eocene Zeitz formation, Saxony, Germany. Geochim. Cosmochim. Acta 2001, 65, 3505-3527. [CrossRef]

7. Otto, A.; Simoneit, B.R.T.; Wilde, V. Initial results on the biomarker composition of resinites and "Affenhaar" from the Middle Eocene lignites of the Geiseltal (Sachsen-Anhalt, Germany). Hallesches Jahrb. Geowiss. B 2001, 13, 57-68.

8. Otto, A.; White, J.D.; Simoneit, B.R.T. Natural product terpenoids in Eocene and Miocene conifer fossils. Science 2002, 297, 1543-1545. [CrossRef] [PubMed]

9. Otto, A.; Simoneit, B.R.T.; Wilde, V. Terpenoids as chemosystematic markers in selected fossil and extant species of pine (Pinus, Pinaceae). Bot. J. Linn. Soc. 2007, 154, 129-140. [CrossRef]

10. Medeiros, P.M.; Simoneit, B.R.T. Multi-biomarker characterization of sedimentary organic carbon in small rivers draining the northwestern United States. Org. Geochem. 2008, 39, 52-74. [CrossRef]

11. Evershed, R.P. Organic residue analysis in archaeology: The archaeological biomarker revolution. Archaeometry 2008, 50, 895-924. [CrossRef]

12. Menor-Salván, C.; Najarro, M.; Velasco, F.; Rosales, I.; Tornos, F.; Simoneit, B.R.T. Terpenoids in extracts of Lower Cretaceous ambers from the Basque-Cantabrian basin (El Soplao, Cantabria, Spain): Paleochemotaxonomic aspects. Org. Geochem. 2010, 41, 1089-1103. [CrossRef]

13. Schnell, G.; Schaeffer, P.; Tardiron, H.; Motsch, E.; Connan, J.; Ertlen, D.; Schwarz, D.; Schneider, N.; Adam, P. Contrasting diagenetic pathways of higher plant triterpenoids in buried wood as a function of tree species. Org. Geochem. 2014, 66, 107-124. [CrossRef]

14. Stefanova, M.; Simoneit, B.R.T.; Marinov, S.P.; Zdravkov, A.; Kortenski, J. Novel polar biomarkers of the Miocene Maritza-East lignite, Bulgaria. Org. Geochem. 2016, 96, 1-10. [CrossRef]

15. González, M.A. Aromatic abietane diterpenoids: Their biological activity and synthesis. Nat. Prod. Rep. 2015, 32, 684-704. [CrossRef]

16. Otto, A.; Wilde, V. Sesqui-, di-, and triterpenoids as chemosystematic markers in extant conifers-A review. Bot. Rev. 2001, 67, 141-238. [CrossRef]

17. Cox, R.E.; Yamamoto, S.; Otto, A.; Simoneit, B.R.T. Oxygenated di- and tricyclic diterpenoids of southern hemisphere conifers. Biochem. Syst. Ecol. 2007, 35, 342-362. [CrossRef]

18. Anderson, K.B. The nature and fate of natural resins in the geosphere. XII. Investigation of C-ring aromatic diterpenoids in Raritan amber by pyrolysis-GC-matrix isolation FTIR-MS. Geochem. Trans. 2006, 7, 2-10. [CrossRef] [PubMed]

19. Sonibare, O.O.; Huang, R.-J.; Jacob, D.E.; Nie, Y.; Kleine-Benne, E.; Hoffmann, T.; Foley, S.F. Terpenoid composition and chemotaxonomic aspects of Miocene amber from the Koroglu Mountains, Turkey. J. Anal. Appl. Pyrolysis 2014, 105, 100-107. [CrossRef]

20. Carman, R.M.; Deeth, H.C. Diterpenoids XIV. 4-Epidehydroabietic acid from the oleoresin of Callitris columellaris F. Muell. Aust. J. Chem. 1967, 20, 2789-2793. [CrossRef]

21. Carman, R.M.; Deeth, H.C. Diterpenoids XXVI. A new diterpenoid acid from the oleoresin of Callitris columellaris. Aust. J. Chem. 1971, 24, 353-359. [CrossRef]

22. Zhang, H.; Sun, H. Diterpenoids from Rabdosia kunmingensis. Phytochemistry 1989, 28, 3405-3409.

23. Lee, C.K.; Fang, J.M.; Cheng, Y.S. Abietanes from leaves of Juniperus chinensis. Phytochemistry 1994, 35, 983-986. [CrossRef]

24. Zhang, G.-J.; Li, Y.-H.; Jiang, J.-D.; Yu, S.-S.; Qu, J.; Ma, S.-G.; Liu, Y.-B.; Yu, D.-Q. Anti-Coxsackie virus B diterpenes from the roots of Illicium jiadifengpi. Tetrahedron 2013, 69, 1017-1023. [CrossRef]

25. Brecknell, D.J.; Carman, R.M. Callitrin, callitrisin, dihydrocallitrisin, columellarin and dihydrocolumellarin, new sesquiterpene lactones from the heartwood of Callitris columellaris. Tetrahedron Lett. 1978, 19, 73-76. [CrossRef] 
26. Brecknell, D.J.; Carman, R.M. Novel sesquiterpene lactones from Callitris columellaris heartwood. Aust. J. Chem. 1979, 32, 2455-2471. [CrossRef]

27. Doimo, L. Azulenes, costols and $\gamma$-lactones from cypress-pines (Callitris columellaris, C. glaucophylla and C. intratropica) distilled oils and methanol extracts. J. Essent. Oil Res. 2001, 13, 25-29. [CrossRef]

28. Aynechi, Y. Deoxypodophyllotoxin, the cytotoxic principle of Callitris columellaris. J. Pharm. Sci. 1971, 60, 121-122. [CrossRef]

29. Van Uden, W.; Pras, N. The accumulation of podophyllotoxin- $\beta$-D-glucoside by cell suspension cultures derived from the conifer Callitris drummondii. Plant Cell Rep. 1990, 9, 257-260. [CrossRef] [PubMed]

30. Van Uden, W. Callitris spp. (cypress pine): In vivo and in vitro accumulation of podophyllotoxin and other secondary metabolites. Biotech. Agric. For. 1993, 24, 92-106.

31. Yamamoto, S.; Cox, R.E.; Simoneit, B.R.T. Gas chromatography/mass spectrometry of the lignans in resin of Callitris preissii. J. Mass Spectrom. Soc. Jpn. 2010, 58, 195-209. [CrossRef]

32. Kovats, E. Gas-chromatographische Charakterisierung organischer Verbindungen. Teil 1. Retentionsindices aliphatischer Halogenide, Alkohole, Aldehyde und Ketone. Helv. Chim. Acta 1958, 41, 1915-1932. [CrossRef]

33. Sy, L.-K.; Brown, G.D. Abietane diterpenes from Illicium angustisepalum. J. Nat. Prod. 1998, 61, 907-912. [CrossRef]

34. Ali, F.; Sangwan, P.L.; Koul, S.; Pandey, A.; Bani, S.; Abdullah, S.T.; Sharma, P.R.; Kitchlu, S.; Khan, I.A. 4-epi-Pimaric acid: A phytomolecule as a potent antibacterial and anti-biofilm agent for oral cavity pathogens. Eur. J. Clin. Microbiol. Infect. Dis. 2011, 31, 149-159. [CrossRef]

35. Cambie, R.C.; Cox, R.E.; Croft, K.D.; Sidwell, D. Phenolic diterpenoids of some Podocarps. Phytochemistry 1983, 22, 1163-1166. [CrossRef]

36. Pinchin, R.; Mayer, L.M.V.; Pinto, A.C. Veadeirol and veadeiroic acid, two novel diterpenes from Vellozia flavicans. Phytochemistry 1978, 17, 1671-1672. [CrossRef]

37. Bevan, C.W.L.; Ekong, D.E.U.; Okogun, J.I. West African timbers. Part XVI. Ozic acid, a new diterpene acid from Daniella ogea. Chem. Commun. 1966, 2, 44-45.

38. Stipanovic, R.D.; O’Brien, D.H.; Rogers, C.E.; Thompson, T.E. Diterpenoid acids, (-)-cis- and (-)-trans-ozic acid, in wild sunflower, Helianthus occidentalis. J. Agric. Food Chem. 1979, 27, 458-459. [CrossRef]

39. Dauben, W.G.; German, V.F. The structure of lambertianic acid: A new diterpenic acid. Tetrahedron 1966, 22, 679-683. [CrossRef]

40. Kitadani, M.; Yoshikoshi, A.; Kitahara, Y.; de Paiva Campello, J.; McChesney, J.D.; Watts, D.J.; Wenkert, E. Natural ar-abietatriene. Chem. Pharm. Bull. 1970, 18, 402-405. [CrossRef]

41. Simoneit, B.R.T.; Mazurek, M.A. Organic matter of the troposphere - II. Natural background of biogenic lipid matter in aerosols over the rural western United States. Atmos. Environ. 1982, 16, 2139-2159. [CrossRef]

42. Simoneit, B.R.T. Cyclic terpenoids of the geosphere. In Biological Markers in the Sedimentary Record; Johns, R.B., Ed.; Elsevier Science Publishing Company: New York, NY, USA, 1986; pp. 43-99.

43. Jaffé, R.; Wolff, G.A.; Cabrera, A.C.; Carvajal-Chitty, H. The biogeochemistry of lipids in rivers from the Orinoco basin. Geochim. Cosmochim. Acta 1995, 59, 4507-4522. [CrossRef]

44. Wakeham, S.G.; Schaffner, C.; Giger, W. Polycyclic aromatic hydrocarbons in Recent lake sediments II. Compounds derived from biogenic precursors during early diagenesis. Geochim. Cosmochim. Acta 1980, 44, 415-429. [CrossRef]

45. Standley, L.J.; Simoneit, B.R.T. Resin diterpenoids as tracers for biomass combustion aerosols. J. Atmos. Chem. 1994, 18, 1-15. [CrossRef]

46. Shaw, G.W.; Franich, R.A.; Eglinton, G.; Allan, J.; Douglas, A.G. Diterpenoid acids in Yallourn lignite. Phys. Chem. Earth 1980, 12, 281-286. [CrossRef]

47. Eckenwalder, J.E. Re-evaluation of Cupressaceae and Taxodiaceae: A proposed merger. Madrono 1976, 23, 237-256.

48. Gadek, P.A.; Alpers, D.L.; Heslewood, M.M.; Quinn, C.J. Relationships within Cupressaceae sensu lato: A combined morphological and molecular approach. Am. J. Bot. 2000, 87, 1044-1057. [CrossRef] [PubMed]

49. Tabacik, C.; Poisson, C. Diterpènes de Juniperus phoenicea: Constituants mineurs. Phytochemistry 1971, 10, 1639-1645. [CrossRef] 
50. Barrero, A.F.; Quilez de Moral, J.F.; Mar Herrador, M.; Akssira, M.; Bennamara, A.; Akkad, S.; Aitigri, M. Oxygenated diterpenes and other constituents from Moroccan Juniperus phoenicea and Juniperus thurifera var. africana. Phytochemistry 2004, 65, 2507-2515. [CrossRef]

51. Paull, R.; Hill, R.S. Early Oligocene Callitris and Fitzroya (Cupressaceae) from Tasmania. Am. J. Bot. 2010, 97, 809-820. [CrossRef]

Sample Availability: Not available.

(C) 2018 by the authors. Licensee MDPI, Basel, Switzerland. This article is an open access article distributed under the terms and conditions of the Creative Commons Attribution (CC BY) license (http://creativecommons.org/licenses/by/4.0/). 